\title{
PENERAPAN RADIAL BASIS FUNCTION NEURAL NETWORK DALAM PENGKLASIFIKASIAN DAERAH TERTINGGAL DI INDONESIA
}

\author{
Vira Wahyuningrum ${ }^{1}$ \\ ${ }^{1}$ Badan Pusat Statistik Provinsi Jawa Barat \\ e-mail: ${ }^{1}$ vira.2w@bps.go.id
}

\begin{abstract}
Abstrak
Penetapan daerah tertinggal di Indonesia merupakan kasus pengklasifikasian dengan dua kategori pada variabel respon (biner). Pengklasifikasian dengan metode klasifikasi linier yang umum digunakan yaitu regresi logistik pada tahap eksplorasi data menghasilkan misclassification yang relatif besar, sehingga diperlukan suatu metode alternatif. Artificial Neural Network (ANN) merupakan alternatif yang menjanjikan untuk berbagai metode klasifikasi konvensional. Radial Basis Function Neural Network (RBFNN) merupakan salah satu arsitektur ANN yang populer digunakan dalam klasifikasi. Metode RBFNN menggunakan dua pendekatan yaitu supervised dan unsupervised serta dalam beberapa penelitian menghasilkan akurasi klasifikasi yang tinggi. Penelitian ini bertujuan menerapkan metode RBFNN untuk kasus klasifikasi daerah tertinggal di Indonesia untuk melihat arsitektur RBFNN yang terbentuk dan ketepatan klasifikasi yang dihasilkan. Hasil dari penelitian ini adalah penerapan RBFNN memberikan performa yang sangat baik yaitu nilai akurasi sebesar 93,48 persen, sensitivitas 81,10 persen dan spesifikasi 97,43 persen. Nilai F-Measure arsitektur RBFNN yang dihasilkan mencapai 85,36 persen.
\end{abstract}

Kata kunci: Neural Network, Radial Basis Function, klasifikasi, daerah tertinggal

\begin{abstract}
Determination of underdeveloped regency in Indonesia is the case with the classification of two categories on the response variable (binary). Classification with the linear classification method that is commonly used is logistic regression at the data exploration stage resulting in relatively large misclassification, so we need an alternative method. Artificial Neural Network (ANN) is a promising alternative to various conventional classification methods. Radial Basis Function Neural Network (RBFNN) is one of the popular ANN architectures used in classification. The RBFNN method uses two approaches namely supervised and unsupervised and in several studies produces high classification accuracy. This study aims to apply the RBFNN method for the classification case of underdeveloped regency in Indonesia to see the RBFNN architecture formed and the resulting classification accuracy. The results of this study are the application of RBFNN provides an excellent performance that is an accuracy value of 93.48 percent, sensitivity 81.10 percent and 97.43 percent specifications. The F-Measure value of RBFNN architecture reached 85.36 percent.
\end{abstract}

Keywords: Neural Network, Radial Basis Function, Classification, Underdeveloped regency 


\section{PENDAHULUAN}

Pembangunan Daerah Tertinggal (PDT) merupakan suatu proses, upaya, dan tindakan secara terencana untuk meningkatkan kualitas masyarakat dan wilayah yang merupakan bagian integral dari pembangunan nasional. Percepatan PDT dimulai dengan pengidentifikasian daerah tertinggal oleh Kementerian Negara Pembangunan Daerah Tertinggal (KNPDT) dengan menggunakan kriteria yang telah ditetapkan. Status daerah sebagai daerah tertinggal ditetapkan oleh Presiden melalui Peraturan Pemerintah. Berdasarkan penetapan tersebut, KNPDT kemudian bekerja sama dengan kementeriankementerian lain dan pemerintah daerah untuk menyusun strategi percepatan PDT.

Pengklasifikasian daerah tertinggal di Indonesia menggunakan variabel yang telah digunakan sebelumnya oleh KNPDT dengan suatu metode statistik merupakan kajian yang menarik. Hasil pengklasifikasian dengan metode statistik dapat dibandingkan ketepatannya dengan hasil penetapan daerah tertinggal oleh KNPDT. Klasifikasi merupakan pengelompokan objek ke beberapa kelompok berdasarkan variabel yang diamati. Klasifikasi daerah tertinggal merupakan kasus klasifikasi dengan dua kategori pada variabel respon (biner/dikotomi). Data yang digunakan dalam pengklasifikasian daerah tertinggal melibatkan 27 variabel dalam enam kriteria yang sangat kompleks.

Metode klasifikasi yang sering digunakan untuk data dengan respon kategorik atau biner adalah metode regresi logistik. Namun, pada regresi logistik dan metode klasifikasi klasik lainnya diperlukan asumsi awal yang harus dipenuhi agar diperoleh hasil klasifikasi yang optimal. Metode regresi logistik memiliki syarat pemenuhan asumsi diantaranya tidak terjadinya multikolinieritas pada variabel prediktornya. Dalam penelitian di bidang sosial, masalah multikolinieritas seringkali tidak bisa dihindari sehingga asumsi independensi tidak terpenuhi. Berdasarkan hasil eksplorasi data untuk mendeteksi multikolinieritas dengan nilai Variance Inflation Factor (VIF), terdapat 5 variabel prediktor yang mengandung multikolinieritas pada model regresi daerah tertinggal. Berkaitan dengan hasil eksplorasi data tersebut, metode regresi logistik memiliki keterbatasan untuk digunakan dalam pengklasifikasian daerah tertinggal dengan keseluruhan variabel yang ada. Penggunaan metode regresi logistik dengan pelanggaran asumsi akan mempengaruhi hasil klasifikasi yaitu terjadinya misclassification atau error rate yang relatif besar. Oleh karena itu, diperlukan metode alternatif yang dapat menjadi solusi dalam kasus klasifikasi ini.

Beberapa metode modern dikembangkan sebagai metode alternatif untuk membantu menyelesaikan masalah klasifikasi, salah satunya metode berbasis machine learning yaitu Artificial Neural Network (ANN) atau dikenal juga sebagai Jaringan Syaraf Tiruan (JST). Dalam dekade terakhir, ANN telah muncul sebagai alat menarik untuk pemodelan proses nonlinier, terutama dalam situasi di mana pengembangan fenomenologis atau model regresi konvensional menjadi tidak praktis atau rumit (Živković, 2008). ANN merupakan metode yang dapat menjadi solusi karena mampu melakukan ekstraksi hubungan antara input dan output tanpa asumsi awal dan bekerja berdasarkan informasi dari data yang tersedia. ANN memiliki kemampuan memodelkan permasalahan nonlinier kompleks yang sulit dipecahkan dengan persamaan matematis biasa (Haykin,2008).

ANN dapat diaplikasikan untuk pengklasifikasian daerah tertinggal dengan pertimbangan banyaknya variabel yang digunakan, pola hubungan antar variabel prediktor dan variabel respon yang tidak diketahui dengan jelas dan jumlah observasi yang cukup banyak (491 kabupaten). Selain itu, penelitian-penelitian sebelumnya yang menunjukkan kelebihan metode ANN dalam menyelesaikan masalah klasifikasi sangat mendukung untuk menggunakan metode tersebut dalam penelitian ini. 
Penelitian mengenai klasifikasi daerah tertinggal dilakukan oleh Naibaho (2016) menggunakan metode Back Propagation Neural Network (BPNN) dan Learning Vector Quatization (LVQ) yang menghasilkan kesimpulan bahwa metode LVQ memberikan tingkat akurasi prediksi yang lebih baik daripada BPNN. Selanjutnya, penulis juga telah menerapkan metode Probalilistic Neural Network (PNN) dalam kasus klasifikasi yang sama (Wahyuningrum, 2017). Sitamahalakshmi, dkk (Sitamahalakshmi, dkk, 2011) membandingkan metode Radial Basis Function Neural Network (RBFNN) dan PNN dalam pengenalan karakter Telugu (pola tulisan bahasa Telugu di India) dan menghasilkan kesimpulan bahwa akurasi metode RBFNN secara keseluruhan lebih baik dibandingkan PNN. Metode RBFNN dipilih dalam penelitian ini karena merupakan arsitektur yang populer digunakan dalam klasifikasi. RBFNN bersifat feed forward, tipe jaringan (multilayer) serta keunggulan fungsi aktivasi yang digunakan. Berdasarkan uraian tersebut, penelitian ini bertujuan menerapkan metode RBFNN dalam pengklasifikasian daerah tertinggal di Indonesia untuk mendapatkan model/arsitektur dan melihat performa klasifikasi yang dihasilkan oleh metode tersebut.

\section{METODOLOGI PENELITIAN}

\section{Tinjauan Referensi}

\section{Klasifikasi Daerah Tertinggal}

Daerah tertinggal adalah daerah kabupaten yang wilayah serta masyarakatnya kurang berkembang dibandingkan dengan daerah lain dalam skala nasional. Pemerintah menetapkan 122 kabupaten di Indonesia sebagai daerah tertinggal tahun 2015-2019 dalam Peraturan Pemerintah Nomor 131 Tahun 2015. Penetapan daerah tertinggal dilakukan lima tahun sekali dan dilakukan evaluasi pada setiap tahun. Dalam Keputusan Menteri Negara PDT RI No.001/KEP/M-PDT/I/2005, suatu daerah dikategorikan sebagai daerah tertinggal dikarenakan beberapa faktor penyebab, antara lain faktor geografis, sumber daya alam, sumber daya manusia, sarana dan prasarana, daerah rawan bencana dan konflik sosial, serta kebijakan pembangunan.

Penetapan kriteria daerah tertinggal dilakukan dengan menggunakan pendekatan berdasarkan pada 6 kriteria dasar, yaitu : (i) perekonomian masyarakat, (ii) sumber daya manusia, (iii) prasarana (infrastruktur), (iv) kemampuan keuangan daerah, (v) aksesibilitas, dan (vi) karakteristik daerah (KNPDT dalam Naibaho, 2016). Keenam kriteria tersebut dibagi menjadi beberapa variabel sebagai dasar penetapan daerah tertinggal dengan total sebanyak 27 variabel (Lampiran). Klasifikasi daerah termasuk tertinggal atau tidak tertinggal ditentukan berdasarkan hasil perhitungan indeks dari nilai 27 standardized indicators masing-masing daerah.

Berdasarkan Panduan Penjelasan Penetapan Daerah Tertinggal yang disusun oleh KNPDT, secara ringkas tahapan penentuan daerah tertinggal adalah sebagai berikut (Naibaho, 2016):

1. Data dasar yang digunakan adalah data yang bersumber dari Podes, Susenas dan Kemampuan Keuangan Daerah (KKD) sebanyak 27 variabel.

2. Dilakukan standarisasi variabel karena satuan masing-masing variabel tidak sama. Tujuan standarisasi agar dapat diperbandingkan antar variabel.

3. Dari hasil standardisasi veriabel, selanjutnya dilakukan perkalian dengan bobot untuk masing-masing variabel.

4. Indikator dari hasil perkalian standarisasi variabel dengan masingmasing bobot variabel ditentukan arahnya berupa tanda positif atau negatif. Variabel seperti jumlah prasarana atau kemampuan keuangan daerah mempunyai arah yang negatif, dan sebaliknya. Selanjutnya dilakukan penjumlahan indeks.

5. Hasil total indeks ini yang dijadikan patokan penetapan daerah tertinggal, dimana daerah-daerah yang memiliki 
total indeks di atas 0 merupakan daerah tertinggal.

\section{Artificial Neural Network (ANN)}

ANN atau dikenal juga dengan Neural Network (NN) atau JST merupakan suatu jaringan syaraf yang dibangun untuk meniru cara kerja otak manusia. ANN adalah sistem pemroses informasi yang memiliki karakteristik mirip dengan jaringan syaraf biologi (Fausett, 1994). ANN tercipta dari suatu generalisasi model matematis dari pemahaman manusia (human cognition) yang berdasarkan pada asumsi berikut:

1. Pemrosesan informasi terjadi pada elemen sederhana (neuron).

2. Sinyal mengalir di antara neuron melalui suatu penghubung.

3. Setiap penghubung antara neuron satu dengan lainnya mempunyai bobot/weight.

4. Setiap neuron akan menerapkan suatu fungsi aktivasi (biasanya nonlinier) terhadap inputnya (hasil penjumlahan sinyal yang dibobot) untuk menentukan sinyal outputnya.

Karakteristik dari ANN antara lain meliputi bentuk/pola hubungan antar neuron yang disebut sebagai arsitektur, metode untuk menentukan bobot hubungan yang disebut sebagai pelatihan (training)/algoritma dan fungsi aktivasi. Arsitektur NN merupakan pengaturan neuron ke dalam lapisan, pola hubungan dalam lapisan, dan di antara lapisan (Fausset, 1994). Arsitektur NN antara lain jaringan dengan lapisan tunggal (Single Layer Net), jaringan dengan banyak lapisan (Multilayer Net) dan jaringan Kompetitif (Competitive Layer).

Secara umum proses pembelajaran pada NN digolongkan menjadi dua, yaitu:

1. Supervised learning (pembelajaran dengan pengawasan), yaitu jaringan diberikan target yang akan dicapai sebagai dasar untuk mengubah bobot pada jaringan.

2. Unsupervised learning (pembelajaran tanpa pengawasan), yaitu jaringan mengorganisasikan sendiri bobot dalam jaringan berdaarkan parameter tanpa adanya target.

Beberapa metode/arsitektur yang dapat digunakan dalam pengklasifikasian menggunakan ANN diantaranya BPNN, PNN, RBFNN dan LVQ.

\section{Metode Analisis}

\section{Radial Basis Function Neural Network (RBFNN)}

RBFNN merupakan arsitektur dari ANN yang bersifat feed forward dan dapat melakukan proses klasifikasi dengan waktu singkat. RBFNN melakukan proses pembelajaran yang sangat cepat karena neuron disetel secara lokal (Sitamahalakshmi, dkk, 2011). RBFNN merupakan metode jaringan syaraf tiruan yang menggunakan fungsi aktivasi radial basis dan umum dipakai dalam kasus klasifikasi dan prediksi/peramalan. Dalam beberapa penelitian, metode RBFNN dimodifikasi dengan pendekatan $K$-means cluster dan fungsi aktivasi Gaussian sehingga meningkatkan keakurasian hasil klasifikasi. Waktu pelatihan (training) pada jaringan RBFNN sangat cepat dan memiliki kemampuan generalisasi yang baik (Sitamahalaksmi,dkk, 2011). RBFNN dapat mengatasi beberapa keterbatasan BPNN karena menggunakan hidden layer tunggal untuk pemodelan fungsi nonlinier, sehingga mampu melatih data lebih cepat dari BPNN (Ghaderzadeh, dkk, 2013). RBFNN adalah teknik alternatif yang menarik untuk masalah klasifikasi (Kotsiantis, dkk, 2007).

RBFNN menggunakan radial basis function yaitu Gaussian. Fungsi aktivasi Gaussian merupakan fungsi yang memperhitungkan jarak atau kedekatan antara data dengan pusat data. Fungsi Gaussian mempunyai sifat lokal, yaitu bila input dekat dengan rata-rata (pusat), maka fungsi akan menghasilkan nilai 1, sedangkan bila input jauh dari rata-rata maka fungsi akan memberikan nilai nol. Selain itu fungsi Gaussian merupakan salah satu radial basis function yang memberikan hasil terbaik dalam pengenalan pola. Jaringan RBFNN termasuk dalam tipe jaringan ANN dengan banyak lapisan atau biasa disebut dengan multilayer. RBFNN 
dalam proses klasifikasi menghitung bobot jarak Gaussian dengan pusat cluster.

RBFNN pertama kali diformulasikan oleh D.S. Broomhead dan David Lowe pada sebuah penelitian tahun 1988. RBFNN mempunyai satu lapisan tersembunyi/hidden layer dengan fungsi aktivasi radial basis dan lapisan output. Jaringan RBFNN merupakan jaringan yang unik karena menggunakan dua pendekatan dalam metodenya yaitu supervised dan unsupervised. Proses pembelajaran RBFNN hanya dilakukan satu arah dan sekali saja. Jaringan syaraf tiruan fungsi radial basis biasanya membutuhkan jumlah neuron yang lebih banyak daripada jaringan feedforward (Kusumadewi, 2003). Pada RBFNN, input akan diolah oleh suatu fungsi aktivasi dan bukan merupakan hasil penjumlahan terbobot dari data input, namun berupa vektor jarak antara vektor bobot dan vektor input yang dikalikan dengan bobot bias.

RBFNN merupakan arsitektur ANN yang dikenal sangat cepat dalam melakukan proses pembelajaran (training). Kelebihan jaringan RBFNN antara lain waktu pelatihan yang lebih cepat dibandingkan Multilayer Perceptron (MLP) dan interpretasi hidden layer pada RBFNN lebih mudah dibandingkan hidden layer pada MLP. Sedangkan kelemahannya, pada RBFNN generalisasi tidak begitu baik dan terlalu fleksibel, sehingga menyebabkan terjadinya noise pada saat pelatihan dan menyebabkan kesalahan prediksi (Devega, 2013).

RBFNN terdiri dari tiga lapisan/layer yaitu input layer, hidden layer dan output layer. Setiap neuron/unit pada input layer sesuai dengan komponen dari vektor masukan. Hidden layer adalah satu-satunya lapisan tersembunyi dalam RBFNN yang berlaku transformasi nonlinier dari input layer ke dalam hidden layer dengan menggunakan fungsi aktivasi nonlinier. Dengan menggunakan algoritma $K$-Mean Cluster, pola pelatihan pada hidden layer akan terkelompok ke dalam jumlah yang wajar. Output layer terdiri dari neuron linier terhubung ke semua neuron tersembunyi. Jumlah neuron pada output layer sama dengan jumlah kelas data target. Arsitektur RBFNN digambarkan sebagai berikut (Sitamahalakshmi, dkk, 2011):

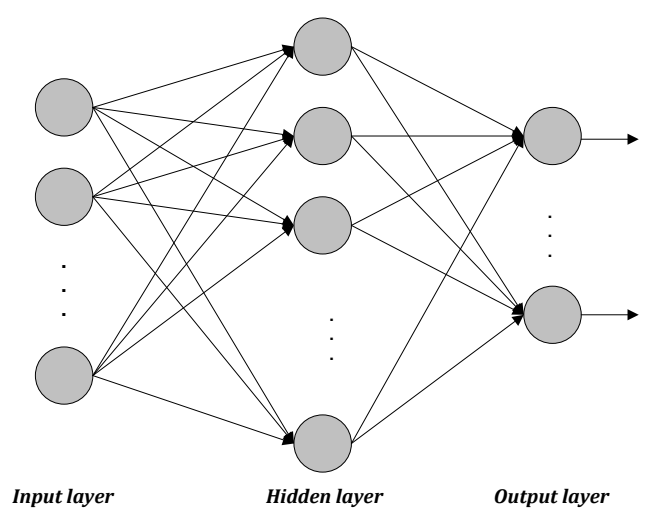

Gambar 1. Arsitektur RBFNN

Output dari setiap neuron pada hidden layer dihitung dengan menggunakan fungsi radial basis Gaussian sebagai berikut (Sitamahalakshmi, dkk, 2011):

$G\left(\left\|x-\mu_{i}\right\|\right)=\exp \left(-\frac{\left\|x-\mu_{i}\right\|^{2}}{2 \sigma^{2}}\right)$.

di mana,

$x$ : sampel pelatihan

$\mu_{i}$ : pusat dari neuron ke i pada hidden layer

$\sigma:$ lebar neuron (spread)

Neuron output didefinisikan oleh fungsi penjumlahan berikut (Sitamahalakshmi, dkk, 2011):

$$
Y(x)=\sum_{i} w G\left(\left\|x-\mu_{i}\right\|\right)+b \text {. }
$$

Di mana $\mathrm{b}$ adalah bobot bias dan $\mathrm{w}$ adalah vektor bobot yang dihitung dengan mengalikan pseudoinverse dari matriks $\mathrm{G}$ dengan vektor target (d) dari data training dengan rumus (Sitamahalakshmi, dkk, 2011):

$$
w=\left(G^{T} G\right)^{-1} G^{T} d .
$$

Hal yang khusus pada RBFNN adalah pemrosesan sinyal dari input layer ke hidden layer bersifat nonlinier, sedangkan dari hidden layer ke ouput layer bersifat linier. Pada hidden layer digunakan sebuah fungsi aktivasi berbasis radial untuk membawa input menuju lapisan (layer) berikutnya. Dari beberapa fungsi aktivasi, fungsi Gaussian merupakan fungsi aktivasi yang paling sering digunakan dalam metode 
RBFNN karena mempunyai sifat lokal, berdasarkan jarak/ kedekatan input dengan rata-rata (pusat cluster). Hidden layer pada RBFNN dapat dilihat sebagai fungsi yang memetakan pola input dari ruang nonlinier ke ruang linier. Pada hidden layer, kekuatan diskriminatif jaringan ditentukan oleh pusat Radial Basis Function (RBF). Ada beberapa metode yang berbeda untuk memilih pusat/centroid, namun yang paling sering digunakan adalah $K$-means cluster.

Tahap pembelajaran unsupervised pada RBFNN adalah menentukan mean dan standar deviasi dari variabel input pada setiap node pada unit hidden layer. Metode K-Mean Cluster adalah salah satu dari beberapa metode unsupervised pada pemodelan RBFNN. Metode K-means cluster digunakan untuk menemukan satu set pusat yang lebih akurat mencerminkan distribusi titik data. Jumlah pusat diputuskan di awal dan setiap pusat seharusnya mewakili sekelompok titik data. Pada metode $K$-means cluster, data dipartisi kedalam K cluster. Penentuan nilai rata-rata dari setiap cluster dilakukan dengan iterasi.

Dalam metode RBFNN terdapat sejumlah parameter (weight) yang harus ditaksir. Untuk mendapatkan model RBFNN yang sesuai, perlu menentukan kombinasi yang tepat antara jumlah variabel input, jumlah node (cluster) pada unit hidden layers, mean dan standar deviasi (skala atau width) dari variabel input pada setiap node, yang berimplikasi pada jumlah parameter yang optimal.

\section{Performa Klasifikasi}

Salah satu cara untuk mengevaluasi performa suatu metode klasifikasi/ klasifikator adalah dengan menggunakan confusion matrix. Dari confusion matrix ini dapat dihitung beberapa parameter untuk mengukur performa klasifikasi. Menurut Han (Han dkk., 2011), confusion matrix merupakan alat yang sangat berguna untuk menganalisis seberapa baik klasifikator mengenali objek dari kelas yang berbeda. Elemen dari confusion matrix didefinisikan sebagai TP:True Positive (benar positif); FP: False Positive (salah positif); FN: False Negative (salah negatif) ; dan TN: True Negative (benar negatif).

Parameter penting dalam pengukuran performa klasifikasi yang dapat diukur berdasarkan confusion matrix adalah akurasi, sensitivitas dan spesifikasi. Akurasi didefinisikan sebagai perbandingan antara jumlah diagonal utama confusion matrix dengan jumlah keseluruhan objek. Nilai akurasi yang semakin mendekati $100 \%$ menunjukkan performa klasifikator semakin tinggi/ baik. Sensitivitas atau disebut juga recall merupakan ukuran nilai ketepatan dari suatu kejadian yang diinginkan (benar positif). Sedangkan spesifikasi adalah persentase dari suatu kejadian yang tidak diinginkan (benar negatif). Formulasi penghitungan akurasi, sensitivitas dan spesifikasi berdasarkan confusion matrix dituliskan dalam persamaan berikut (Ghaderzadeh,dkk, 2013) :

$$
\begin{aligned}
& \text { Akurasi }=\frac{T P+T N}{T P+T N+F P+F N} \times 100 \% \\
& \text { Sensitivitas }=\frac{T P}{T P+F N} \times 100 \% \\
& \text { Spesifikasi }=\frac{T N}{F P+T N} \times 100 \%
\end{aligned}
$$

Nilai error rate juga dipakai untuk menentukan performa hasil klasifikasi di mana nilai ini menunjukkan tingkat kesalahan klasifikasi (misclassification)

Tabel 1. Confusion Matrix dengan Respon Biner untuk Klasifikasi Daerah Tertinggal

\begin{tabular}{|l|c|c|c|}
\hline \multicolumn{1}{|c|}{ Prediksi } & $\begin{array}{c}\text { Daerah Tertinggal } \\
(\mathrm{Y}=1)\end{array}$ & $\begin{array}{c}\text { Daerah Tidak Tertinggal } \\
(\mathrm{Y}=0)\end{array}$ & Total \\
\hline $\begin{array}{l}\text { Daerah Tertinggal } \\
(\mathrm{Y}=1)\end{array}$ & $T P$ & $\begin{array}{c}F N \\
\text { (type II } \text { error })\end{array}$ & $T P+F N$ \\
\hline $\begin{array}{l}\text { Daerah Tidak Tertinggal } \\
(\mathrm{Y}=0)\end{array}$ & $\begin{array}{c}F P \\
\text { (type I error) }\end{array}$ & $T N$ & $F P+T N$ \\
\hline Total & $T P+F P$ & $F N+T N$ & $T P+T N+F P+F N$ \\
\hline
\end{tabular}


atau kelas prediksi yang tidak sesuai dengan kelas aktualnya. Semakin semakin rendah nilai misclassification maka semakin baik klasifikator, dan sebaliknya.

missclassification $(\%)=100-$ akurasi

F-Measure dapat digunakan sebagai ukuran tunggal dari uji performa klasifikasi yang merupakan ukuran rata-rata harmonik dari sensitivitas (recall) dan precision. Recall dan precision adalah dua ukuran penting untuk mengevaluasi kebenaran algoritma klasifikasi. F-Measure diformulasikan sebagai berikut (Sitamahalakshmi, dkk, 2011):

$F-$ Measure $=\frac{2 * \text { precision } * \text { recall }}{(\text { precision }+ \text { recall })} \times 100 \%$

Penghitungan precision menggunakan rumus berikut:

precision $=\frac{T P}{T P+F P} \times 100 \%$

F-Measure menggabungkan ukuran recall dan precision dengan nilai maksimum adalah 1. Bila nilai tersebut semakin mendekati 1 atau 100 persen, maka kinerja classifier (algoritma klasifikasi) dianggap semakin baik.

\section{Sumber Data dan Variabel}

Penelitian ini menggunakan data sekunder meliputi 27 variabel yang digunakan oleh Kementerian Negara Pembangunan Daerah Tertinggal dan Transmigrasi (KNPDT) dalam penetapan daerah tertinggal dan tidak tertinggal di Indonesia. Variabel input yang digunakan diantaranya berasal dari data Potensi Desa dan data Survei Sosial Ekonomi Nasional (Susenas) dari BPS serta data Kemampuan Keuangan Daerah (KKD) dari Kemenkeu. Penelitian ini menggunakan data sebanyak $491 \mathrm{kabupaten} /$ kota di Indonesia. Variabel output (Y) merupakan output biner yaitu daerah tertinggal $(\mathrm{Y}=1)$ dan daerah tidak tertinggal $(\mathrm{Y}=0)$.

Sebelum dilakukan pengolahan data, perlu dilakukan pre-processing data untuk menyamakan satuan pada 27 variabel input melalui standarisasi. Standarisasi dilakukan dengan mengurangkan setiap nilai variabel $\mathrm{x}$ dengan rata-rata pada variabel tersebut dan membagi dengan standar deviasinya (s). Standarisasi nilai input akan menghasilkan nilai pada range[-1,1].

\section{Tahapan Penelitian}

Langkah-langkah yang akan dilakukan dalam pengklasfikasian daerah tertinggal dengan metode RBFNN sebagai berikut:

1. Menyiapkan pre-processing data yang akan digunakan (standarisasi variabel input)

Tabel 2. Arsitektur RBFNN pada Klasifikasi Daerah Tertinggal

\begin{tabular}{|c|c|}
\hline Parameter & Detail \\
\hline Data Sampel & Data Training (90\%), Data Testing (10\%) \\
\hline Cross Validation & $\mathrm{k}-$ Fold $(\mathrm{k}=10)$ \\
\hline Standarisasi Nilai Input & Range $[-1,1]$ \\
\hline Pembelajaran & Kombinasi Supervised (terawasi) dan Unsupervised \\
\hline Fungsi Aktivasi & $\begin{array}{l}\text { Gaussian } \\
\qquad G\left(\left\|x-\mu_{i}\right\|\right)=\exp \left(-\frac{\left\|x-\mu_{i}\right\|^{2}}{2 \sigma^{2}}\right)\end{array}$ \\
\hline Jumlah Layer & 1 input layer, 1 hidden layer, 1 output layer \\
\hline Jumlah Neuron & $\begin{array}{l}\text { Input layer }=27 \text { (jumlah variabel } \text { input }) \\
\text { Hidden Layer }=\text { jumlah } \text { cluster }(k \text {-means cluster }) \\
\text { Output Layer }=2(\text { jumlah kelas data } \text { output })\end{array}$ \\
\hline
\end{tabular}


2. Membagi data menjadi 10 bagian $(\mathrm{k}=10)$ untuk $k$-Fold cross validation.

3. Menentukan jumlah cluster pada hidden layer dan melakukan klasifikasi menggunakan metode RBFNN pada data training dan data testing untuk masingmasing fold/bagian.

4. Menghitung performa klasifikasi meliputi akurasi, sensitivitas, dan spesifikasi dan F-Measure

5. Kesimpulan penelitian

\section{HASIL DAN PEMBAHASAN}

Penelitian ini meggunakan metode $k$ fold cross validation yaitu membagi data ke dalam $\mathrm{k}$ bagian (fold) secara acak dengan ukuran fold yang mendekati sama, di mana $\mathrm{k}$ adalah jumlah bagian yang ditentukan. Nilai $k$ yang sering digunakan dalam penelitian adalah 10 (Priddy, 2005). Pembagian data training dan data testing berdasarkan 10-fold cross validation untuk 491 sampel yang digunakan dan selanjutnya dilakukan klasifikasi menggunakan RBFNN pada data training dan data testing.

RBFNN merupakan jaringan dengan arsitektur yang terdiri atas 3 layer meliputi input layer, hidden layer dan output layer. Pada input layer terdapat sejumlah neuron yang merupakan jumlah variabel yang digunakan dalam pengklasifikasian yaitu sebanyak 27 variabel. Banyaknya neuron pada output layer RBFNN sama dengan jumlah kelas data yaitu 2 neuron. Banyak neuron pada hidden layer sebanyak cluster yang digunakan dalam model pengklasifikasian. Center cluster pada penelitian ini ditentukan dengan algoritma $K$-means cluster, dan jumlah cluster $(\mathrm{K})$ yang diuji ditentukan pada nilai $\mathrm{K}=2$ sampai dengan $K=100$. Rata-rata akurasi paling tinggi dihasilkan pada jumlah cluster k=34 yaitu sebesar 93,48 persen, sedangkan akurasi paling rendah pada jumlah cluster sebanyak 82 yaitu 75,57 persen. Oleh karena itu, jumlah cluster yang dipilih dalam arsitektur RBFNN ini adalah 34.

Jumlah cluster yang digunakan menggambarkan banyaknya neuron pada hidden layer RBFNN. Dengan demikian, arsitektur RBFNN yang dipilih dalam pengklasifikasian daerah tertinggal adalah RBFNN (27-34-2) tersusun oleh 27 neuron pada input layer, 34 neuron pada hidden layer dan 2 neuron pada output layer.

Akurasi yang dihasilkan dengan arsitektur RBFNN (27-34-2) dari data training melalui 10 percobaan 10-fold cross validation berkisar antara 89,80 hingga 97,96 persen. Hasil testing dari 10 fold menunjukkan akurasi paling tinggi pada

Tabel 3. Pembagian Data Menggunakan 10-Fold cross validation

\begin{tabular}{|l|c|c|c|c|c|c|c|c|c|c|}
\hline \multicolumn{1}{|c|}{ Data Sampel } & 1 & 2 & 3 & 4 & 5 & 6 & 7 & 8 & 9 & 10 \\
\hline Data Training & 441 & 442 & 442 & 442 & 442 & 442 & 442 & 442 & 442 & 442 \\
\hline Data Testing & 50 & 49 & 49 & 49 & 49 & 49 & 49 & 49 & 49 & 49 \\
\hline
\end{tabular}

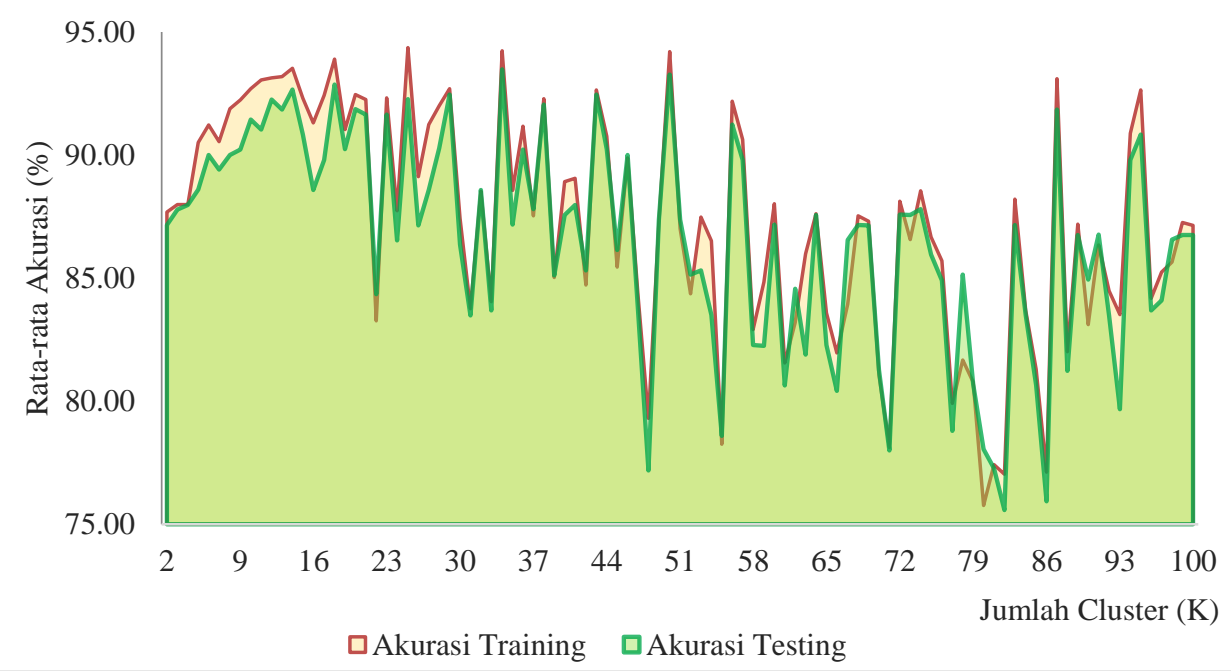

Gambar 2. Akurasi Klasifikasi RBFNN Menurut Jumlah Cluster (persen) 


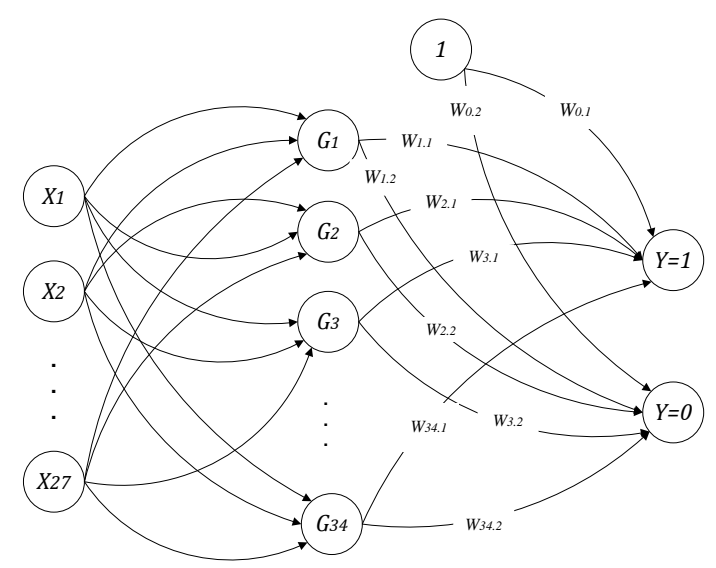

diklasifikasikan sesuai data aktualnya dan hanya 1 daerah yang diklasifikasikan berbeda dengan data aktualnya. Overfitting (akurasi hasil klasifikasi data training lebih tinggi daripada data testing) arsitektur RBFNN (27-34-2) ini terjadi pada 6 dari 10 percobaan.

Sensitivitas arsitektur RBFNN (2734-2) dari data testing fold 6 menunjukkan persentase paling tinggi yaitu sebesar 92,31

Gambar 3. Arsitektur RBFNN (27-34-2)

fold 6, artinya dengan menggunakan arsitektur RBFNN, dari 49 data testing dalam fold tersebut, 48 daerah berhasil

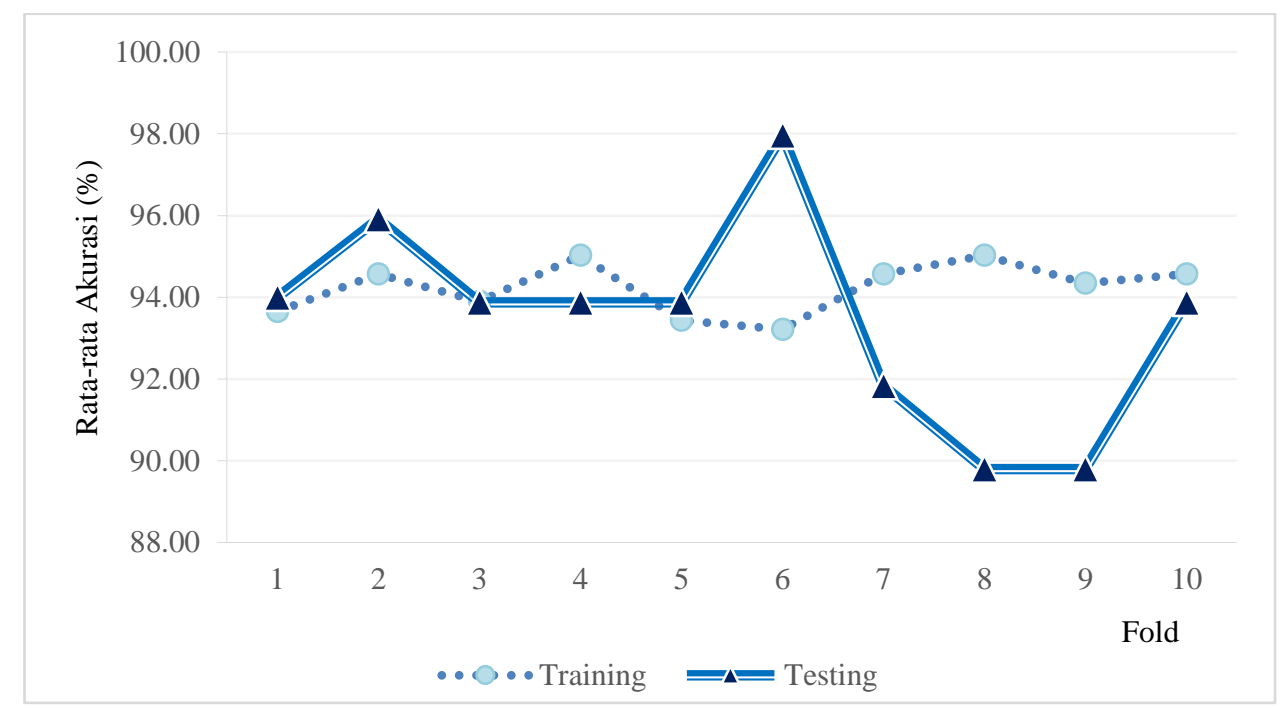

Gambar 4. Ketepatan Hasil Klasifikasi dengan RBFNN (27-34-2)

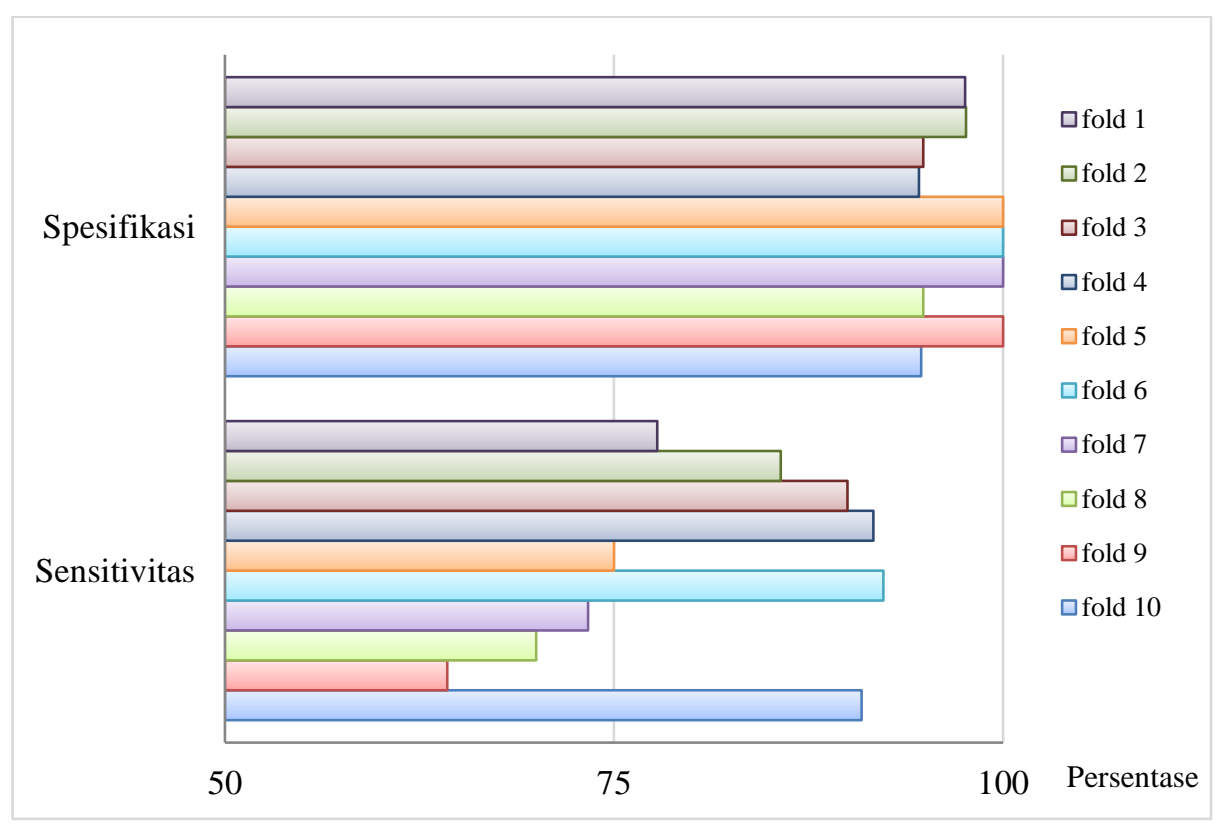

Gambar 5. Sensitivitas dan Spesifikasi Hasil Klasifikasi RBFNN Menurut Fold 
Tabel 4. Rata-rata Misclassification RBFNN (27-34-2) Hasil Klasifikasi

\begin{tabular}{|l|c|c|}
\hline \multicolumn{1}{|c|}{ Metode RBFNN } & Rata-rata Akurasi & $\begin{array}{c}\text { Rata-rata Misclassification } \\
\text { (100-Akurasi)\% }\end{array}$ \\
\hline Data Training & 94,23 & 5,77 \\
\hline Data Testing & 93,48 & 6,52 \\
\hline
\end{tabular}

Tabel 5. F-Measure Arsitektur RBFNN (27-34-2)

\begin{tabular}{|c|c|c|c|c|c|}
\hline Metode & True Positive & False Positive & Precison & Sensitivitas (Recall) & F-Measure \\
\hline RBFNN & 91 & 10 & 90,10 & 81,10 & 85,36 \\
\hline
\end{tabular}

persen yang berarti bahwa arsitektur RBFNN memberikan ketepatan klasifikasi sebesar 92,31 persen dalam mengklasifikasikan daerah tertinggal. Spesifikasi atau ketepatan klasifikasi daerah tertinggal dengan model RBFNN pada fold 5, fold 6 , fold 7 dan fold 9 mencapai 100 persen, yang berarti keseluruhan daerah tidak tertinggal dalam keempat fold ini diklasifikasikan secara tepat sesuai dengan aktualnya. Testing fold 10 memberikan spesifikasi terendah, yaitu 94,74 persen dari daerah tidak tertinggal yang diklasifikasikan dengan tepat sesuai status sebenarnya sebagai daerah tidak tertinggal.

Rata-rata akurasi yang dihasilkan berdasarkan 10-fold cross validation pada arsitektur RBFNN (27-34-2) mencapai 93,48 persen. Rata-rata sensitivitas yang menggambarkan kemampuan jaringan alam mengklasifikasikan daerah tertinggal sesuai data aktualnya memberikan hasil sebesar 81,10 persen. Untuk spesifikasi, RBFNN mampu menghasilkan ketepatan klasifikasi daerah tidak tertinggal sebesar 97,43 persen.

Secara umum, berdasarkan evaluasi performa klasifikasi dengan menggunakan arsitektur RBFNN (27-34-2) diperoleh hasil performa klasifikasi yang baik. RBFNN memiliki kelemahan pada sensitivitas namun unggul dalam spesifikasi. Rata-rata misclassification dari model RBFNN sebesar 6,52 persen dengan hasil misclassification sebanyak 32 daerah. Misclassification pada RBFNN meliputi 22 daerah tertinggal yang diklasifikasikan sebagai daerah tidak tertinggal dan 10 daerah tidak tertinggal yang diklasifikasikan sebagai daerah tertinggal. Daftar daerah yang mengalami misclassification dari total 10 fold data testing dapat dilihat pada Lampiran.

Misclassification merupakan besarnya kesalahan klasifikasi pada hasil prediksi dibandingkan data aktual. Ratarata Misclassification yang dihasilkan dari data training sebesar 5,77 persen, sedangkan pada data testing sedikit meningkat menjadi sebesar 6,52 persen.

F-Measure merupakan ukuran tunggal dari uji performa klasifikasi berdasarkan sensitivitas (recall) dan precision. Nilai F-Measure dari RBFNN sebesar 85,36 persen, artinya kinerja algoritma RBFNN dianggap baik (mendekati 100 persen semakin baik). Dalam sudut pandang metode RBFNN sebagai metode yang relatif akurat untuk pengklasifikasian daerah tertinggal di Indonesia, data misclassification yang dihasilkan dapat menjadi perhatian untuk dikaji lebih lanjut ataupun menjadi pertimbangan dalam penentuan kebijakan bagi stakeholder dan pihak yang terkait. Data hasil klasifikasi dengan metode RBFNN ini dapat menjadi pembanding untuk penentuan status daerah tertinggal pada periode mendatang.

\section{KESIMPULAN DAN SARAN}

Pada pengklasifikasian dengan RBFNN, dengan algoritma $k$-means cluster didapatkan jumlah cluster sebanyak 34 cluster, sehingga arsitektur yang terbentuk adalah RBFNN (27-34-2). Arsitektur ini tersusun oleh 27 neuron pada input layer, 
34 neuron pada hiddenn layer, dan 2 neuron pada output layer. Dari segi ukuran arsitektur model, RBFNN cukup efisien dengan lebih sedikit neuron pada hidden layer (sesuai jumlah cluster). Rata-rata performa klasifikasi berdasarkan 10-fold cross validation yang diperoleh dengan RBFNN (27-34-2) yaitu akurasi 93,48 persen, sensitivitas 81,10 persen, spesifikasi 97,43 persen. Berdasarkan evaluasi performa klasifikasi dari arsitektur RBFNN dapat disimpulkan bahwa metode RBFNN memiliki keunggulan pada spesifikasi. Untuk performa klasifikasi secara keseluruhan, RBFNN menghasilkan nilai F-Measure sebesar 85,36 persen.

Untuk pengembangan penelitian, dapat dilakukan pengklasifikasian dengan menggunakan penggabungan (hybrid) model, misalnya model Radial Basis Probabilistic Neural Network (RBPNN) yang merupakan kombinasi dari arsitektur jaringan RBFNN dengan PNN. RBPNN memadukan keunggulan dari kedua model yang digabungkan sehingga diharapkan dapat meningkatkan performa klasifikasi yang dihasilkan. Metose RBFNN ini juga dapat diterapkan pada pemodelan klasifikasi dengan lebih banyak variabel dan cakupan data.

\section{DAFTAR PUSTAKA}

Devega, Mariza. 2013. Diagnosa Kerusakan Bantalan Gelinding Menggunakan Metode RBFNN. Tesis. Semarang: Universitas Diponegoro.

Fausett, L. 1994. Fundamentals of Neural Networks: Architectures, Algorithms and Applications. Prentice-Hall, New Jersey, USA.

Ghaderzadeh, M., Fein, R., Standring, A. 2013. Early Detection of Cancer from Benign Hyperplasia of Prostate. Applied Medical Informatics Vol. 33, No. 3, pp: 45-54

Han, J., Kamber, M., \& Pei, J. (2011). Data Mining Concepts and Techniques Third Edition. Waltham: Elsevier Inc.

Haykin, S. 2008. Neural Networks and Learning Machines. New Jersey: Prentice Hall.
Kotsiantis, S., Zaharakis, I., Pintelas, P. 2007. Supervised machine learning: A review of classification techniques. Frontiers in Artificial Intelligence and Applications.

Kusumadewi, S. 2003. Artificial Intelligence (Teknik dan

Aplikasinya). Yogyakarta (ID): Graha Ilmu.

Naibaho, E. 2016. Perbandingan Back Propagation Neural Network dan Learning Vector Quatization. Tesis. Bandung: Universitas Padjajaran

Priddy, K.L., Keller, P.E. 2005. Artificial Neural Network : An Introduction. Washington: Spie Press

Sitamahalakshmi, T., et al. 2011. Performance Comparison of Radial Basis Function Networks and Probabilistic Neural Networks for Telugu Character Recognition. Global Journal of Computer Science and Technology Volume 11 Issue 4

Wahyuningrum, V.2017. Classification of Underdeveloped Regency using Probabilistic Neural Networks. Proceeding International Conference (ICAS), Vol.2 No 1 (2017)

Živković, Ž., Mihajlović,I., Nikolić,D. 2008. Artificial Neural Network Method Applied on The Nonlinear Multivariate Problems. University of Belgrade, Serbia 


\section{LAMPIRAN}

Daftar Variabel Output (Y) dan Variabel Input (X)

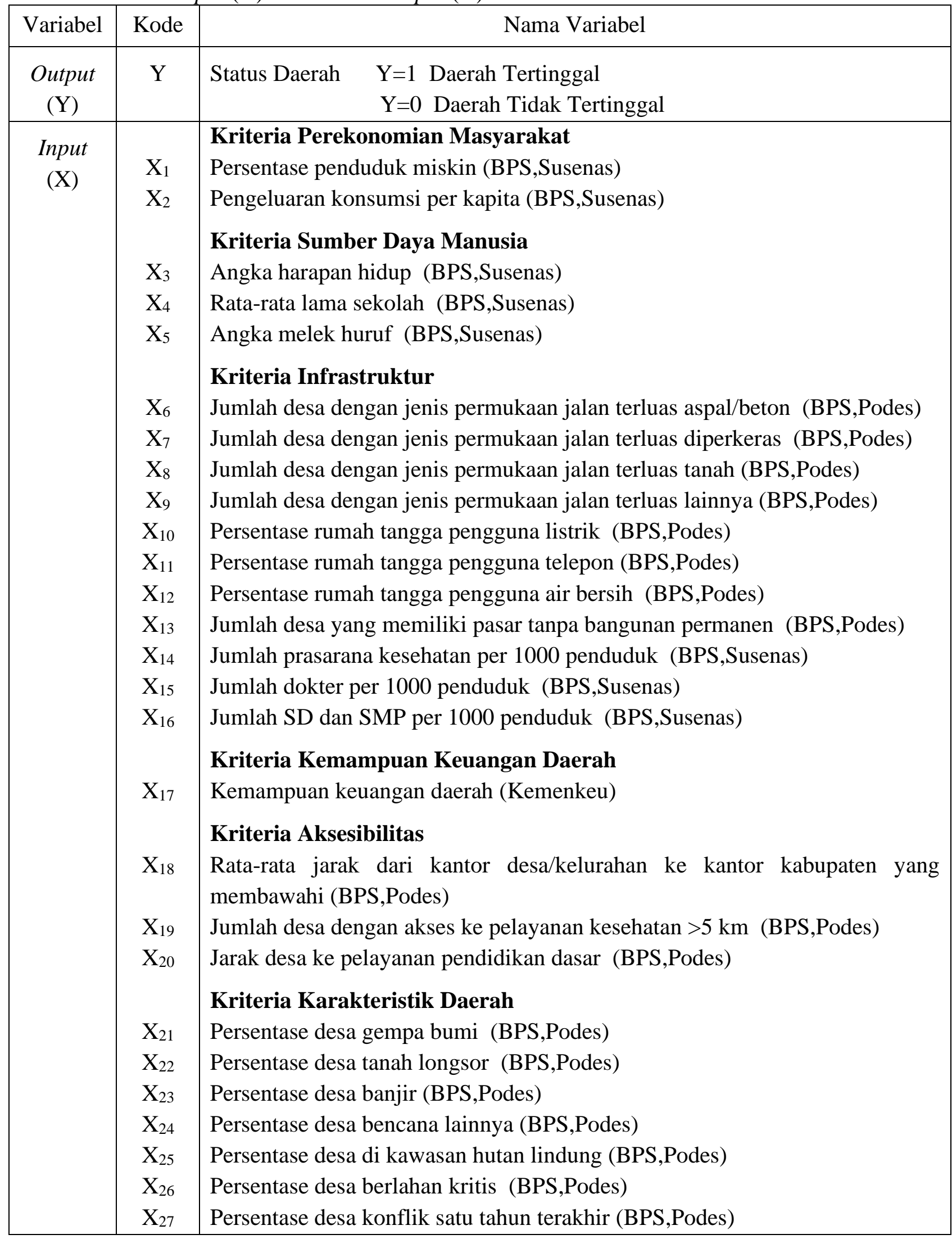


Hasil Eksplorasi Data: Uji Multikolinieritas dan Output Regresi Logistik

\section{UJI MULTIKOLINIERITAS}

VIF $>5$ artinya variabel mengandung masalah multikolinieritas

$>$ data<-read.csv("dataNN.csv")

$>$

$\operatorname{glm}(\mathrm{Y} 2015 \sim \mathrm{X} 1+\mathrm{X} 2+\mathrm{X} 3+\mathrm{X} 4+\mathrm{X} 5+\mathrm{X} 6+\mathrm{X} 7+\mathrm{X} 8+\mathrm{X} 9+\mathrm{X} 10+\mathrm{X} 11+\mathrm{X} 12+\mathrm{X} 13+\mathrm{X} 14+\mathrm{X} 15+\mathrm{X} 16+\mathrm{X} 17+$ $\mathrm{X} 18+\mathrm{X} 19+\mathrm{X} 20+\mathrm{X} 21+\mathrm{X} 22+\mathrm{X} 23+\mathrm{X} 24+\mathrm{X} 25+\mathrm{X} 26+\mathrm{X} 27$, data $=$ data $)$

$>$ vif(reg.log)

$\begin{array}{llllllll}X 1 & X 2 & X 3 & X 4 & X 5 & X 6 & X 7 & X 8\end{array}$

2.8310222 .2532911 .5623335 .5400245 .6553493 .1481601 .5178143 .439646

$\begin{array}{lllllll}X 9 & X 10 & X 11 & \text { X12 } & \text { X13 } & \text { X14 } & \text { X15 X16 }\end{array}$

2.2748094 .9223622 .7520092 .3349731 .4632567 .9594013 .3196616 .485056

$\begin{array}{llllllll}X 17 & \text { X18 } & \text { X19 } & \text { X20 } & \text { X21 } & \text { X22 } & \text { X23 } & \text { X24 }\end{array}$

1.5779842 .0193355 .4295714 .2803631 .1946681 .3272431 .2415771 .219430

X25 X26 X27

1.8587471 .4891841 .243659

\section{REGRESI LOGISTIK}

data<-read.csv("dataNN.csv")

$\mathrm{kab}<-$ data[,1]

data[,1] <- NULL

train2<-sample(nrow(data),round $(0.9 *$ nrow(data) $))$

data_train2<-data\$Y_2015[train2]

data_test $<$-data\$Y_2015[-train2]

fit $<$-glm(Y_2015 , ,data=data[train2,],family="binomial")

logistics.train2<-fit\$fitted.value \#\#prediction

mat.logis.train2<-table(round(data\$Y_2015[train2]),round(logistics.train2,0)) \#confusion matrix

acc.logis.train2<-sum(diag(mat.logis.train2))/sum(mat.logis.train2) \#accuracy

logistics.test<-predict(fit,newdata=data[-train2,],type="response") \#\#prediction

mat.logis.test<-table(round(data\$Y_2015[-train2]),round(logistics.test,0)) \#confusion matrix

acc.logis.test<-sum(diag(mat.logis.test))/sum(mat.logis.test) \#accuracy

result.acc.training $2<-\mathrm{c}($ acc.logis.train2) \#\#akurasi training

result.acc.testing $2<-\mathrm{c}$ (acc.logis.test)

result<-rbind(result.acc.training2,result.acc.testing2)

colnames(result)<-c("Logistics Regression")

rownames(result)<-c("Training", "Testing")

result

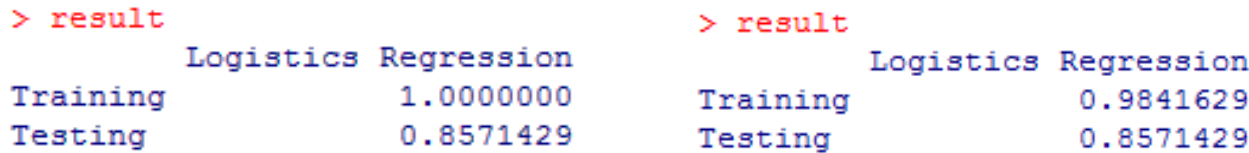

0.8571429 Testing

0.8571429

Ringkasan Data Penelitian

\begin{tabular}{|c|l|c|c|c|c|r|}
\hline $\begin{array}{c}\text { No. } \\
\text { Urut }\end{array}$ & \multicolumn{1}{|c|}{ Nama Kabupaten } & $\mathrm{Y}$ & $\mathrm{X}_{1}$ & \multicolumn{1}{c|}{$\mathrm{X}_{2}$} & $\ldots$ & \multicolumn{1}{c|}{$\mathrm{X}_{27}$} \\
\hline 1 & SIMEULUE & 0 & 20,57 & 628,09 & $\ldots$ & 0,00 \\
\hline 2 & ACEH SINGKIL & 1 & 18,73 & 620,40 & $\ldots$ & 3,33 \\
\hline 3 & ACEH SELATAN & 0 & 13,44 & 616,71 & $\ldots$ & 0,38 \\
\hline 4 & ACEH TENGGARA & 0 & 14,39 & 609,76 & $\ldots$ & 4,16 \\
\hline 5 & ACEH TIMUR & 0 & 16,59 & 599,27 & $\ldots$ & 0,58 \\
\hline & & & & & & \\
. &. &. &. &. &. &. \\
. &. &. &. &. &. &. \\
\hline
\end{tabular}




\begin{tabular}{|c|c|c|c|c|c|c|}
\hline 490 & DEIYAI & 1 & 47,52 & 593,06 & $\ldots$ & 0,00 \\
\hline 491 & JAYAPURA & 0 & 16,19 & 650,99 & $\ldots$ & 5,13 \\
\hline
\end{tabular}

Sumber: BPS dan Kemenkeu, diolah

Ringkasan Data Hasil Standarisasi Variabel Input (X)

\begin{tabular}{|c|l|l|l|l|l|}
\hline $\begin{array}{c}\text { No. } \\
\text { Urut }\end{array}$ & \multicolumn{1}{|c|}{ Nama Kabupaten } & $\mathrm{X}_{1}$ & $\mathrm{X}_{2}$ & $\ldots$ & $\mathrm{X}_{27}$ \\
\hline 1 & SIMEULUE & 0,41119 & 0,81892 & $\ldots$ & 0,00000 \\
\hline 2 & ACEH SINGKIL & 0,37099 & 0,78362 & $\ldots$ & 0,08772 \\
\hline 3 & ACEH SELATAN & 0,25541 & 0,76669 & $\ldots$ & 0,01012 \\
\hline 4 & ACEH TENGGARA & 0,27616 & 0,73478 & $\ldots$ & 0,10936 \\
\hline 5 & ACEH TIMUR & 0,32423 & 0,68663 & $\ldots$ & 0,01536 \\
\hline & & & & & \\
$\cdot$ & $\cdot$ & $\cdot$ & $\cdot$ & $\cdot$ & $\cdot$ \\
$\cdot$ & $\cdot$ & $\cdot$ & $\cdot$ & $\cdot$ & $\cdot$ \\
\hline 490 & DEIYAI & 1,00000 & 0,65813 & $\ldots$ & 0,00000 \\
\hline 491 & JAYAPURA & 0,31549 & 0,92403 & $\ldots$ & 0,13495 \\
\hline
\end{tabular}

Sumber: Hasil Pengolahan

Pembagian Data Berdasarkan 10-Fold cross validation

\begin{tabular}{|l|l|l|l|l|l|l|l|l|l|l|}
\hline Fold & 1 & 2 & 3 & 4 & 5 & 6 & 7 & 8 & 9 & 10 \\
\hline Fold 1 & 50 & 50 & 50 & 50 & 50 & 50 & 50 & 50 & 50 & 50 \\
\hline Fold 2 & 49 & 49 & 49 & 49 & 49 & 49 & 49 & 49 & 49 & 49 \\
\hline Fold 3 & 49 & 49 & 49 & 49 & 49 & 49 & 49 & 49 & 49 & 49 \\
\hline Fold 4 & 49 & 49 & 49 & 49 & 49 & 49 & 49 & 49 & 49 & 49 \\
\hline Fold 5 & 49 & 49 & 49 & 49 & 49 & 49 & 49 & 49 & 49 & 49 \\
\hline Fold 6 & 49 & 49 & 49 & 49 & 49 & 49 & 49 & 49 & 49 & 49 \\
\hline Fold 7 & 49 & 49 & 49 & 49 & 49 & 49 & 49 & 49 & 49 & 49 \\
\hline Fold 8 & 49 & 49 & 49 & 49 & 49 & 49 & 49 & 49 & 49 & 49 \\
\hline Fold 9 & 49 & 49 & 49 & 49 & 49 & 49 & 49 & 49 & 49 & 49 \\
\hline Fold 10 & 49 & 49 & 49 & .49 & .49 & .49 & 49 & 49 & 49 & 49 \\
\hline
\end{tabular}

\begin{tabular}{|l|l|l|}
\hline $\begin{array}{l}\text { Data } \\
\text { Sampel }\end{array}$ & $\begin{array}{l}\text { Data } \\
\text { Trainin } \\
g\end{array}$ & $\begin{array}{l}\text { Data } \\
\text { Testing }\end{array}$ \\
\hline 1 & 441 & 50 \\
\hline 2 & 442 & 49 \\
\hline 3 & 442 & 49 \\
\hline 4 & 442 & 49 \\
\hline 5 & 442 & 49 \\
\hline 6 & 442 & 49 \\
\hline 7 & 442 & 49 \\
\hline 8 & 442 & 49 \\
\hline 9 & 442 & 49 \\
\hline 10 & 442 & 49 \\
\hline
\end{tabular}

116.

$$
\begin{array}{|l|l|}
\hline \text { H.Data Training } & \text { Data Testing } \\
\hline
\end{array}
$$

Rata-rata Akurasi Training dan Testing RBFNN Menurut Jumlah Cluster ( $k$-means cluster)

\begin{tabular}{|c|c|c|}
\hline $\begin{array}{c}\text { Cluster } \\
(k)\end{array}$ & $\begin{array}{c}\text { Akurasi } \\
\text { Training }\end{array}$ & $\begin{array}{c}\text { Akurasi } \\
\text { Testing }\end{array}$ \\
\hline 2 & 0,8769 & 0,8716 \\
\hline 3 & 0,8798 & 0,8778 \\
\hline 4 & 0,8798 & 0,8798 \\
\hline 5 & 0,9052 & 0,8859 \\
\hline 6 & 0,9122 & 0,9001 \\
\hline 7 & 0,9054 & 0,8940 \\
\hline 8 & 0,9188 & 0,9001 \\
\hline 9 & 0,9224 & 0,9022 \\
\hline 10 & 0,9269 & 0,9144 \\
\hline
\end{tabular}

\begin{tabular}{|c|c|c|}
\hline $\begin{array}{c}\text { Cluster } \\
(k)\end{array}$ & $\begin{array}{c}\text { Akurasi } \\
\text { Training }\end{array}$ & $\begin{array}{c}\text { Akurasi } \\
\text { Testing }\end{array}$ \\
\hline 35 & 0,8857 & 0,8718 \\
\hline 36 & 0,9118 & 0,9022 \\
\hline 37 & 0,8753 & 0,8781 \\
\hline 38 & 0,9228 & 0,9206 \\
\hline 39 & 0,8502 & 0,8512 \\
\hline 40 & 0,8891 & 0,8756 \\
\hline 41 & 0,8905 & 0,8798 \\
\hline 42 & 0,8473 & 0,8531 \\
\hline 43 & 0,9265 & 0,9246 \\
\hline
\end{tabular}

\begin{tabular}{|c|c|c|}
\hline $\begin{array}{c}\text { Cluster } \\
(k)\end{array}$ & $\begin{array}{c}\text { Akurasi } \\
\text { Training }\end{array}$ & $\begin{array}{c}\text { Akurasi } \\
\text { Testing }\end{array}$ \\
\hline 68 & 0,8753 & 0,8716 \\
\hline 69 & 0,8731 & 0,8715 \\
\hline 70 & 0,8106 & 0,8126 \\
\hline 71 & 0,7812 & 0,7800 \\
\hline 72 & 0,8812 & 0,8759 \\
\hline 73 & 0,8656 & 0,8756 \\
\hline 74 & 0,8855 & 0,8780 \\
\hline 75 & 0,8667 & 0,8596 \\
\hline 76 & 0,8570 & 0,8491 \\
\hline
\end{tabular}

50 | Jurnal Aplikasi Statistika \& Komputasi Statistik V.12.1.2020, ISSN 2086-4132 


\begin{tabular}{|l|l|l|}
\hline 11 & 0,9305 & 0,9103 \\
\hline 12 & 0,9314 & 0,9226 \\
\hline 13 & 0,9319 & 0,9185 \\
\hline 14 & 0,9353 & 0,9266 \\
\hline 15 & 0,9231 & 0,9083 \\
\hline 16 & 0,9131 & 0,8859 \\
\hline 17 & 0,9242 & 0,8981 \\
\hline 18 & 0,9389 & 0,9287 \\
\hline 19 & 0,9104 & 0,9025 \\
\hline 20 & 0,9246 & 0,9187 \\
\hline 21 & 0,9226 & 0,9165 \\
\hline 22 & 0,8327 & 0,8435 \\
\hline 23 & 0,9233 & 0,9164 \\
\hline 24 & 0,8774 & 0,8654 \\
\hline 25 & 0,9437 & 0,9227 \\
\hline 26 & 0,8912 & 0,8715 \\
\hline 27 & 0,9124 & 0,8858 \\
\hline 28 & 0,9201 & 0,9028 \\
\hline 29 & 0,9269 & 0,9246 \\
\hline 30 & 0,8744 & 0,8636 \\
\hline 31 & 0,8375 & 0,8348 \\
\hline 32 & 0,8853 & 0,8858 \\
\hline 33 & 0,8405 & 0,8369 \\
\hline $\mathbf{3 4}$ & $\mathbf{0 , 9 4 2 3}$ & $\mathbf{0 , 9 3 4 8}$ \\
\hline
\end{tabular}

\begin{tabular}{|l|l|l|}
\hline 44 & 0,9076 & 0,9024 \\
\hline 45 & 0,8545 & 0,8614 \\
\hline 46 & 0,8989 & 0,9001 \\
\hline 47 & 0,8430 & 0,8369 \\
\hline 48 & 0,7930 & 0,7718 \\
\hline 49 & 0,8724 & 0,8736 \\
\hline 50 & 0,9421 & 0,9328 \\
\hline 51 & 0,8701 & 0,8737 \\
\hline 53 & 0,8436 & 0,8514 \\
\hline 53 & 0,8749 & 0,8532 \\
\hline 54 & 0,8651 & 0,8350 \\
\hline 55 & 0,7826 & 0,7859 \\
\hline 56 & 0,9219 & 0,9123 \\
\hline 57 & 0,9063 & 0,8981 \\
\hline 58 & 0,8291 & 0,8228 \\
\hline 59 & 0,8484 & 0,8226 \\
\hline 60 & 0,8803 & 0,8718 \\
\hline 61 & 0,8156 & 0,8065 \\
\hline 62 & 0,8321 & 0,8456 \\
\hline 63 & 0,8599 & 0,8189 \\
\hline 64 & 0,8762 & 0,8756 \\
\hline 65 & 0,8359 & 0,8228 \\
\hline 66 & 0,8197 & 0,8042 \\
\hline 67 & 0,8394 & 0,8654 \\
\hline & & \\
\hline
\end{tabular}

\begin{tabular}{|l|l|l|}
\hline 77 & 0,7991 & 0,7879 \\
\hline 78 & 0,8167 & 0,8514 \\
\hline 79 & 0,8078 & 0,8070 \\
\hline 80 & 0,7576 & 0,7804 \\
\hline 81 & 0,7743 & 0,7727 \\
\hline 82 & 0,7703 & 0,7557 \\
\hline 83 & 0,8821 & 0,8716 \\
\hline 84 & 0,8368 & 0,8351 \\
\hline 85 & 0,8131 & 0,8065 \\
\hline 86 & 0,7713 & 0,7593 \\
\hline 87 & 0,9310 & 0,9185 \\
\hline 88 & 0,8201 & 0,8123 \\
\hline 89 & 0,8719 & 0,8675 \\
\hline 90 & 0,8312 & 0,8493 \\
\hline 91 & 0,8635 & 0,8678 \\
\hline 92 & 0,8448 & 0,8348 \\
\hline 93 & 0,8352 & 0,7968 \\
\hline 94 & 0,9088 & 0,8981 \\
\hline 95 & 0,9265 & 0,9083 \\
\hline 96 & 0,8418 & 0,8369 \\
\hline 97 & 0,8525 & 0,8409 \\
\hline 98 & 0,8565 & 0,8657 \\
\hline 99 & 0,8726 & 0,8675 \\
\hline 100 & 0,8715 & 0,8676 \\
\hline & & \\
\hline
\end{tabular}

Sumber: Hasil Pengolahan

Confision matrix Hasil Prediksi RBFNN (27-34-2) Menurut 10-fold cross validation

\begin{tabular}{|l|c|c|c|c|c|}
\hline \multirow{2}{*}{\multicolumn{2}{|c|}{ Aktual }} & \multicolumn{4}{c|}{ Prediksi } \\
\cline { 3 - 6 } \multicolumn{2}{|c|}{} & \multicolumn{3}{|c|}{ RBFNN (27-34-2) } \\
\cline { 2 - 6 } \multicolumn{2}{|c|}{} & 1 & 0 & 1 & 0 \\
\hline \multirow{2}{*}{ Fold 1 } & 1 & 85 & 19 & 7 & 2 \\
\cline { 2 - 6 } & 0 & 9 & 328 & 1 & 40 \\
\hline \multirow{2}{*}{ Fold 2 } & 1 & 90 & 16 & 6 & 1 \\
\cline { 2 - 6 } & 0 & 8 & 328 & 1 & 41 \\
\hline \multirow{2}{*}{ Fold 3 } & 1 & 83 & 20 & 9 & 1 \\
\cline { 2 - 6 } & 0 & 7 & 332 & 2 & 37 \\
\hline \multirow{2}{*}{ Fold 4 } & 1 & 85 & 16 & 11 & 1 \\
\cline { 2 - 6 } & 0 & 6 & 335 & 2 & 35 \\
\hline \multirow{2}{*}{ Fold 5 } & 1 & 79 & 22 & 9 & 3 \\
\cline { 2 - 6 } & 0 & 7 & 334 & 0 & 37 \\
\hline \multirow{2}{*}{ Fold 6 } & 1 & 79 & 21 & 12 & 1 \\
\cline { 2 - 6 } & 0 & 9 & 333 & 0 & 36 \\
\hline \multirow{2}{*}{ Fold 7 } & 1 & 82 & 16 & 11 & 4 \\
\cline { 2 - 6 } & 0 & 8 & 336 & 0 & 34 \\
\hline \multirow{2}{*}{ Fold 8 } & 1 & 87 & 16 & 7 & 3 \\
\cline { 2 - 6 } & 0 & 6 & 333 & 2 & 37 \\
\hline \multirow{2}{*}{ Fold 9 } & 1 & 82 & 17 & 9 & 5 \\
\cline { 2 - 6 } & 0 & 8 & 335 & 0 & 35 \\
\hline \multirow{2}{*}{ Fold 10 } & 1 & 84 & 18 & 10 & 1 \\
\cline { 2 - 6 } & 0 & 6 & 334 & 2 & 36 \\
\hline \multirow{2}{*}{ Total } & 1 & & & 91 & 22 \\
\cline { 2 - 6 } & 0 & & & 10 & 368 \\
\hline \multirow{2}{*}{ Sumber: Hang }
\end{tabular}

Sumber: Hasil Pengolahan

Penerapan Radial Basis Function Neural Network..../Wahyuningrum, Vira| 51 
Performa Klasifikasi Data Training dan Testing dengan Arsitektur RBFNN (27-34-2)

\begin{tabular}{|c|c|c|c|c|c|c|c|c|c|}
\hline \multirow{2}{*}{ Percobaan } & \multicolumn{5}{|c|}{ Training } & \multicolumn{4}{|c|}{ Testing } \\
\hline & M & AK & SV & SP & Lama & M & AK & SV & SP \\
\hline 1 & 6,35 & 93,65 & 81,73 & 97,33 & 4,989 & 6,00 & 94,00 & 77,78 & 97,56 \\
\hline 2 & 5,43 & 94,57 & 84,91 & 97,62 & 4,924 & 4,08 & 95,92 & 85,71 & 97,62 \\
\hline 3 & 6,11 & 93,89 & 80,58 & 97,94 & 4,973 & 6,12 & 93,88 & 90,00 & 94,87 \\
\hline 4 & 4,98 & 95,02 & 84,16 & 98,24 & 4,950 & 6,12 & 93,88 & 91,67 & 94,59 \\
\hline 5 & 6,56 & 93,44 & 78,22 & 97,95 & 5,320 & 6,12 & 93,88 & 75,00 & 100,00 \\
\hline 6 & 6,79 & 93,21 & 79,00 & 97,37 & 5,414 & 2,04 & 97,96 & 92,31 & 100,00 \\
\hline 7 & 5,43 & 94,57 & 83,67 & 97,67 & 23,150 & 8,16 & 91,84 & 73,33 & 100,00 \\
\hline 8 & 4,98 & 95,02 & 84,47 & 98,23 & 5,008 & 10,20 & 89,80 & 70,00 & 94,87 \\
\hline 9 & 5,66 & 94,34 & 82,83 & 97,67 & 4,930 & 10,20 & 89,80 & 64,29 & 100,00 \\
\hline 10 & 5,43 & 94,57 & 82,35 & 98,24 & 5,008 & 6,12 & 93,88 & 90,91 & 94,74 \\
\hline Rata-rata & 5,77 & 94,23 & 82,19 & 97,82 & 6,867 & 6,52 & 93,48 & 81,10 & 97,43 \\
\hline
\end{tabular}

Sumber: Hasil Pengolahan

Keterangan: M (\%Misclassification); AK (\%Akurasi); SV (\%Sensitivitas); SP (\%Spesifikasi); Lama (Waktu Komputasi dalam detik)

Daftar Daerah dengan Prediksi Misclassification per Testing Fold Menggunakan RBFNN (2734-2)

\begin{tabular}{|c|c|c|c|c|}
\hline No. & $\begin{array}{c}\text { Testing } \\
\text { Fold }\end{array}$ & Nama Daerah & Aktual & Prediksi \\
\hline 1 & 1 & KEPULAUAN MERANTI & Tidak Tertinggal & Tertinggal \\
\hline 2 & 1 & MUSI RAWAS & Tertinggal & Tidak Tertinggal \\
\hline 3 & 1 & BOALEMO & Tertinggal & Tidak Tertinggal \\
\hline 4 & 2 & SIMEULUE & Tidak Tertinggal & Tertinggal \\
\hline 5 & 2 & LEBAK & Tertinggal & Tidak Tertinggal \\
\hline 6 & 3 & HALMAHERA UTARA & Tidak Tertinggal & Tertinggal \\
\hline 7 & 3 & BIAK NUMFOR & Tertinggal & Tidak Tertinggal \\
\hline 8 & 3 & KATINGAN & Tidak Tertinggal & Tertinggal \\
\hline 9 & 4 & MANOKWARI & Tidak Tertinggal & Tertinggal \\
\hline 10 & 4 & KAPUAS HULU & Tertinggal & Tidak Tertinggal \\
\hline 11 & 4 & MALUKU TENGGARA & Tidak Tertinggal & Tertinggal \\
\hline 12 & 5 & TOLI-TOLI & Tertinggal & Tidak Tertinggal \\
\hline 13 & 5 & BONDOWOSO & Tertinggal & Tidak Tertinggal \\
\hline 14 & 5 & KEEROM & Tertinggal & Tidak Tertinggal \\
\hline 15 & 6 & NIAS & Tertinggal & Tidak Tertinggal \\
\hline 16 & 7 & SITUBONDO & Tertinggal & Tidak Tertinggal \\
\hline 17 & 7 & HULU SUNGAI UTARA & Tertinggal & Tidak Tertinggal \\
\hline 18 & 7 & BENGKAYANG & Tertinggal & Tidak Tertinggal \\
\hline 19 & 7 & POHUWATO & Tertinggal & Tidak Tertinggal \\
\hline 20 & 8 & NIAS BARAT & Tertinggal & Tidak Tertinggal \\
\hline 21 & 8 & POSO & Tidak Tertinggal & Tertinggal \\
\hline 22 & 8 & NUNUKAN & Tertinggal & Tidak Tertinggal \\
\hline 23 & 8 & SELUMA & Tertinggal & Tidak Tertinggal \\
\hline 24 & 8 & HALMAHERA TENGAH & Tidak Tertinggal & Tertinggal \\
\hline 25 & 9 & PANDEGLANG & Tertinggal & Tidak Tertinggal \\
\hline 26 & 9 & KONAWE & Tertinggal & Tidak Tertinggal \\
\hline 27 & 9 & LAMPUNG BARAT & Tertinggal & Tidak Tertinggal \\
\hline 28 & 9 & BOMBANA & Tertinggal & Tidak Tertinggal \\
\hline 29 & 9 & PASAMAN BARAT & Tertinggal & Tidak Tertinggal \\
\hline
\end{tabular}




\begin{tabular}{|c|c|l|c|c|}
\hline 30 & 10 & KOLAKA UTARA & Tidak Tertinggal & Tertinggal \\
\hline 31 & 10 & PROBOLINGGO & Tidak Tertinggal & Tertinggal \\
\hline 32 & 10 & NABIRE & Tertinggal & Tidak Tertinggal \\
\hline
\end{tabular}

Sumber: Hasil Pengolahan 
